\title{
KŐSZEGFALVI GYÖRGY: MAGYARORSZÁG TELEPÜLÉSRENDSZERE. TÖRTÉNELMI VÁZLAT TELEPÜLÉSRENDSZERÜNKRŐL
}

\author{
(Alexandra Kiadó, Pécs, 2004, 158 o.)
}

\section{PIRISI GÁBOR}

Köszegfalvi György professzor egyike a magyar településügy legkiválóbb ismeröinek. Mủszaki alapvégzettsége felöl közelítve kezdett dolgozni települési és területi tervezési feladatokon, és már érett kutatóként került kapcsolatba a Pécsi Tudományegyetemmel, ahol az 1990-es évek elején oroszlánrészt vállalt a földrajzba integrált terület- és településfejlesztési szakirányú képzés létrehozásában, elindításában. Noha a szerző 2002-es nyugdíjazása óta immár csak alkalmanként tart előadásokat Pécsett, továbbra sem szakadt el a földrajzi mủhelytől. Így, amikor a szakirányú képzésnek azóta gondját viselö Politikai Földrajzi és Területfejlesztési Tanszék új könyvsorozat elindítását tủzte ki céljai közé, természetszerüleg született meg a felkérés annak a munkának a megírására, amely Kőszegfalvi professzor legutóbbi évekbeli munkásságának egyfajta összegzését is jelenti.

A sorozat, amelynek útjára indítása elsősorban dr. Pạp Norbert tanszékvezető egyetemi docens és a pécsi Alexandra Kiadó együttműködésének érdeme, annak az igénynek a jegyében született, hogy a felsőoktatási reform jegyében vélhetỏen tovább bövülő terület- és településfejlesztési oktatás céljaira különbözö témájú, igényes tartalmú, elsösorban felsöoktatási célú szakkönyvek szülessenek. Az elképzelések realizálását egy, a területfejlesztési oktatás szakmai és infrastrukturális hátterét megalapozó projekt sikere tette lehetővé, amely a Phare program keretében, az ERFP-DD2001-HU-B-01 szám alatt nyert el támogatást.

A Magyarország településrendszere könyv öt fejezetre tagolja mondanivalóját, amelyet az alcímben is megfogalmazott módon, elsősorban történelmi dimenzióban tekinti át a problematikát. Az első fejezet döntöen a felhasznált fogalmak értelmezését szolgálja, illetve körüljárja a települések fejlödését. Itt veti fel a szerzó azt a dilemmát is, amely a magyar és a magyarországi településrendszer különbségéből, illetve a magyar államtér történelmi változásaiból fakad. A szerzỏ kitủzött célja a mai Magyarország településrendszerének történelmi vizsgálata, a későbbi fejezetek adatsorait, térképeit is ennek a koncepciónak rendeli alá. Ez érezhetóen kompromisszum: a szerző maga is elismeri, hogy a téma vizsgálata nem nélkülözheti a nagyobb kitekintést, és ezt több helyütt meg is teszi.

A második fejezet a telepúléshálózatot kialakulásától a 20. század elejéig kíséri végig. A súlypont mindenkor a településhálózat csomópontjainak, magasabb hierarchiaszintủ településeinek bemutatásán és a koronként változó településfejlesztỏ tényezők feltárásán van. A fejezetcímben jelzett módon ezeket a hosszúra nyúlt korszakokat a 
szerző a településrendszer kialakulása időszakának tekinti, a következő fejezetek a már létrejött hálózatban megtörténỏ eltolódásokat mutatják be.

Az időbeli tagolódás csomópontjai magától értetődőnek tünnek: a két világháború és a rendszerváltozás egyaránt a településállomány fejlődési lehetőségeit meghatározó feltételrendszer gyökeres átalakulását eredményezték. Az egyes fejezetekben mintha eltérö hangsúlyok érvényesülnének. A két világháború közötti időszakkal foglalkozó rész sokat foglalkozik a településhálózat tudományos igényủ vizsgálatának kezdeteivel, áttekintve a korszak földrajzi, szociológiai vagy néprajzi indíttatású kutatóinak legfontosabb gondolatait.

A negyedik fejezet - A településrendszer helyzete, fejlődése a második világháború utáni évtizedekben - viszont nem meglepő módon elsösorban a tervezés és szabályozás története. Ezen belül külön kitüntetett figyelmet élvez az 1971-es OTK rendszerének bemutatása, illetve hatásainak értékelése, amelynek kapcsán a hatások kettős jellege, a pozitív és negatív vonások egymás mellettisége kapott hangsúlyt.

Az egyes fejezetek nagyjából azonos terjedelemben dolgozzák fel az egyes korszakokat, nincs ez másként az ötödik, ,jelen idejư" résznél sem, hiszen az elemzés hangsúlyozottan alapvetően történelmi jellegü. Így „A magyarországi településrendszer a kilencvenes években" címet viselö utolsó rész lényegében csak arra vállalkozhat, hogy összegezze a történelmi folyamatok eredményeit. A terjedelem arra elegendő, hogy a településhálózat felsőbb szintjeinek térbeli kapcsolatrendszerére, a fejlôdés új hatótényezöire és problémáira felhívja a figyelmet.

Noha természetesen az olvasónak számtalan ötlete támadhat, hogy milyen fejezetekkel, illetve gondolatokkal lehetne még megtoldani a könyvet, az a maga módján mégis komplett egészet alkot. Vállalt célkitüzéseinek következetesen megfelelve, egységes szemléletmódot érvényesít az elemzés teljes idö-intervallumában. A mü elsősorban oktatási céllal íródott. erre - az oktató szemével - kiválóan alkalmas, megfelelő arányban vegyítve a tényeket az elemzésekkel. Gördülékeny stílusa, valamint a fogalmak következetes használata is elösegíti a megértést és az elsajátítást.

A szerző és a szerkesztô reményei szerint a kötet a telepuilési problémákkal foglalkozó, nem feltétlenül geográfus egyetemi és föiskolai hallgatók tetszését is elnyeri. A sorozat természetesen nem áll meg a kezdỏlépés után: a következö kötetek részben megjelenés alatt, részben a nyomdai elökészítés fázisában vannak. 